\title{
WALTER KAUFMANN AND THE FUTURE OF THE HUMANITIES
}

Summary: Walter Kaufmann (1921-1980) is best remembered for his work on Nietzsche. However, from 1950 to the end of his life he produced a wing-raging and provocative body of philosophical criticism. At the heart of Kaufmann's efforts was a concern for the humanities and its role in modern intellectual life. Kaufmann's central meditation on this subject, The Future of the Humanities (1970) deserves more attention that it has received so far. It finds a way to blend two fundamental goals of contemporary theory, a quest of authenticity and the desire to foster a critical spirit. The way Kaufmann achieved these goals, testifying to his ongoing relevance for those who care about the humanities, is the subject of this essay.

Key words: humanities, authenticity, critical spirit.

"...And woe unto all the living that it would live without disputes over weight and scales and weighers!'” Nietzsche, Zarathustra, II, 13

1.

The start of 21 st century may very well be the final era in which the humanities enjoy substantial autonomy and prestige. Advances in genetics, evolutionary and biological psychology, as well as the increasing sophistication of statistical models of behavior prediction, may make current justifications for the study of the humanities sound quaint at best, and obscurantist at worse. To be sure, the end of the humanities has been predicted before, and its decline or demise may never happen. ${ }^{1}$ I am not saying that I want it to happen,

1 An interesting and salutary reminder of how current debates might not be as current as we think can be found in a 1930 essay by Sherlock Bronson Gass entitled "The Well of Discipline," reprinted in Humanism and America, ed. Norman Foerster (Farrar and Reinhardt: 1930). Speaking as a humanist, Gass worried openly about "the contrast between the fruitfulness of the scientific world, its vitality, its harmony, its worldwide cooperation, and our frankly acknowledged moral bankruptcy — vigor 
only that, as Walter Kaufmann put it, "the refusal to reflect on goals invites disaster." In this respect, I think it is best to consider the prospects for the humanities without two implicit, and sentimental, assumptions. They are that, without the humanities, something irreplaceably precious will be lost, and that, once we move beyond the humanities, what would come would certainly be better. We simply don't know how things will look from the standpoint of future generations. ${ }^{3}$ Rather, our task should be to identify what things are most valuable in the humanities, asking ourselves whether our current practices in fact achieve these goals.

To aid in this discussion, I want to turn to Walter Kaufmann who, a generation ago, had some interesting ideas about what was at stake in the study of the humanities. I will present some of Kaufmann's main views on this subject, concentrating on his critique of contemporary education. My overarching goal is to show that his 1977 volume, The Future of the Humanities, is not only worth reading and applying today, but may help the humanities maintain their viability altogether. To reach this end, I will place Kaufmann in his historical context, providing an exposition of his main pedagogical ideas, focusing especially on what he called "the art of reading." 4 Once a picture of Kaufmann's main contribution has emerged, I will finish the piece by linking Kaufmann to a current concern in peda-

and fecundity into the area into which discipline has been shifted and chaos in the area in which discipline has been withdrawn." (p. 283) While Gass's understanding of "moral bankruptcy" may no longer be in perfect accord with contemporary concerns, his sense of alarm that the humanities are not proficient and adequate in the areas where they most need to be is an ongoing one, and thus one that should be addressed with an eye toward the ways it has been treated in the past.

2 Walter Kaufmann (with a new introduction by Saul Goldwasser), The Future of the Humanities: Teaching Art, Religion, Philosophy Literature and History (Transaction Publishers: 1995), first published by Readers Digest Press in 1977. Henceforth, this book is referred to as "TFH."

3 Naturally, the critical nature of present concerns will press for a continual discussion of the future of the humanities, and that of education in general. An especially helpful bibliographic overview of these discussions, particularly as they relate to the future of higher education, is to be found at an Ohio State University website: http:/humanities.osu.edu/news/forums/spring03/bibliography.cfm. In the Spring of 2003, OSU sponsored a forum on the future of the public research university. The useful "readings of interest" they provide underscore the importance of inquiring into the ends of humanities education altogether.

4 For the "art of reading," see pages 47-83 in TFH. 
gogy, namely Gerald Graff's efforts to integrate students into academic "argument culture" by "teaching the conflicts." Though the comparison of Graff to Kaufmann will be critical, the point is neither to dismiss Graff's case utterly, or depreciate his concerns, but to demonstrate how he falls short of his own goals, and how Kaufmann's suggestions can serve to revive them. This sets the stage for an overarching conclusion, where I argue that, while Kaufmann certainly does not reveal the future of the humanities, his ideas about education (primarily, though not exclusively, college education) prepare us well to face our own uncertainties and sense of doubt as to whether or not instructors can convey something of value in the humanities altogether.

2.

Kaufmann (1921-80), longtime professor of philosophy at Princeton, is best remembered for his translations of Nietzsche, along with his general effort at bringing central European thought to the US. ${ }^{6}$ His 1956 anthology, Existentialism from Dostoevsky to Sartre, is still in print. He also wrote several interesting and idiosyncratic philosophical works of his own, primarily in the philosophy of religion, ethics and aesthetics. His works have never fully caught on with academic philosophers, but he has always maintained a certain degree of popularity, both among undergraduates, and a wider reading public. ${ }^{7}$ Kaufmann himself, to some degree, relished this outsider status. His works were sharply critical of what he considered to be a

5 See Graff's 1992 Beyond the Culture Wars: How Teaching the Conflicts can Revitalize American Education (Norton: 1992)and his 2003, Clueless in Academe: How Schooling Obscures the Life of the Mind (Yale U Press: 2003).

6 Kaufmann's main Nietzsche translations can be found in The Portable Nietzsche (Viking: 1977, first published 1954) and The Basic Writings of Nietzsche (The Modern Library: 2000, first published 1967). Kaufmann's own exposition of Nietzsche is found in his Nietzsche: Philosopher, Psychologist, Antichrist (Princeton: 4th edition 1974, first published 1950).

7 This can be seen in a website about Kaufmann hosted by Andrew Spear: http://www.acsu.buffalo.edu/ adspear/Kaufmann\%20entrance.htm. Spear provides a full listing of Kaufmann's writings and reaches a wide variety of readers, academics and non-academics alike. There are not many published studies of Kaufmann's works, though this is changing. Jennifer Ratner-Rosenhagen of the University of Miami has a forthcoming article on Kaufmann, "Dionysian Enlightenment." 
strain of escapism in the professional philosophy of his day. What appealed to him in philosophy was - to adapt Alcibiades' words in the Symposium - its Socratic capacity to make one ashamed of the life he or she is living. ${ }^{8}$ This does not require the philosopher to be completely right, as much as it demands they identify errors and prod others to reach higher. As Kaufmann put it in a 1958 work, long before the notion of "subversion" was fashionable, "philosophy subverts man's satisfaction with himself, exposes custom as a questionable dream, and offers not so much solutions as a different life." ${ }^{9}$ When he turned to pedagogy, therefore, it was not to restore the validity of an enduring canon, nor was it to advocate a new turn, in the direction of relevance. Rather, it was to confront an enduring problem, one made more pressing by the increasing prominence of the sciences. This problem can be defined as one of "blindness." As he put it:

Blindness can be taught and has been for centuries. A great deal of education has always been indoctrination. Students were taught what to see and exhorted not to see inconvenient facts, alternatives, or even their own beliefs. Piety consisted in staying inside, in the dark, believing what you were told. To see for yourself or go outside to find out how your beliefs looked when you stepped back far enough was impiety. ${ }^{10}$

Thus, when he claimed that that, "the sad condition of the humanities should be a matter of vital concern for all of us," he meant that the obvious blindness of previous ages was not really overcome. It was simply replaced with less visible "pieties." $11 \mathrm{He}$ is hardly alone in seeing conformity in academia, ${ }^{12}$ so what, exactly, was his version of the problem?

8 See the Symposium, 216a.

9 Walter Kaufmann, Critique of Religion and Philosophy (Anchor Books: 1958), p. 10. This point is amplified in several other places in Kaufmann's writing. See, especially, his The Faith of a Heretic $(1959,1961)$. There books combine an anti-authoritarianism with a deep respect for tradition. This lays the foundation for the notion Kaufmann developed in The Future of the Humanities that instructors do not need to claim an air of infallibility in order to help students identify errors in the past.

10 TFH, p. 154.

11 TFH, p. xxix

12 Page Smith's Killing the Spirit (Viking: 1990) makes some of the same points, albeit for somewhat different reasons. It is interesting to compare these two works as pendant volumes. 
Put most directly, the problem is that teachers of the humanities fail to read well, and are passing this failure on to their stur dents. ${ }^{13}$ Kaufmann thought the humanities were only justified to the extent that they cultivated what can be called "the authenticity of reading." What this meant was that, "we must allow ourselves to be addressed by a text, we must hearken for its distinctive voice, we must try to discern how it differs from all other voices. We must permit it to challenge shock and offend us." 14 However, in the practices he saw around him, he charged that, "one reads without encountering a You and takes no chances of suffering culture shock." The problem was that, "though written by men and women, the texts are dehumanized and read in a parochial spirit." 15 Even very sophisticated methodological approaches can deflect attention away from a text's individual challenge. ${ }^{16}$

To clarify what he meant Kaufmann identified three strategies of evasion. They are "exegetical," "dogmatic" and "agnostic" reading, and he felt they were common in humanities courses, past as well as present. All are variant ways of not thinking about a text's central problems and the challenges they pose to our view of things. "Exegetes," for Kaufmann, "first endowed the text with authority, then read their own ideas into it, and then got them back endowed with authority." "If the message of the Gospel of St. John is "determined" to be completely compatible with, say, Marxism or existentialism, and

13 The point is made directly on TFH, p. 47, "Reading is the core of the humanities and social sciences, but most students never learn to read well." It is interesting to read these comments in conjunction with what Robert M. Hutchins had said earlier in his Great Books: The Foundation of a Liberal Education (Simon and Schuster: 1954).

14 TFH, p. 63.

15 TFH, p. 59.

${ }^{16}$ In his Discovering the Mind, Volume One: Goethe, Kant and Hegel (Transaction: 1991, first published 1980), Kaufmann went as far as to argue that even an undeniably great philosopher like Kant could advance hypotheses that were a "disaster" (p. 5) when it came to advancing human self-knowledge. A separate discussion would be required to grasp why he said this, but it helps bring out the point that Kaufmann did not presume that taking up the most forbidding ideas of a well-regarded writer was, in and of itself, the royal road to good pedagogy.

17 TFH, p. 48. For a specific illustration of why Kaufmann felt this was the wrong approach, see the critique of Heidegger in Discovering the Mind, Volume Two: Nietzsche, Heidegger and Buber (Transaction: 1991, first published 1980), especially p. 195-97. 
then declared to be true because it is the Bible, we are reading exegetically. This shades into dogmatic reading, whereby readers take the stance, "we know and he doesn't."18 If the books of Islamic Hadith or Jewish Midrash are measured by the standards of Christian theological dogma and then found to be lacking, then, for Kaufmann, this is reading dogmatically. As he put charged, "the dogmatic reader avoids self-exposure, blinds himself to alternatives and objections, and refuses to see what is distinctive in the text and could not just as well be found at home." ${ }^{\prime 19}$ Finally, there is agnostic approach, which revolves around "suspending judgment" about the truth. For Kaufmann, it can take on a myriad of forms, but always involves not thinking about the text's primary messages. The variant that he found most prevalent in his own day was the "microscopic," meaning that "one no longer has breath enough to read a book several times to get a whole view, not to speak of an author's oeuvre. One prefers to study one poem, one passage or one argument. In this way the author is spirited away, the encounter with a challenging You is avoided, and one deals with small pieces that can be taken apart." ${ }^{20}$ If these strategies of evasion are followed, blindness, rather than insight, is taught.

4.

At this point, a reader may wish to raise two objections. First, a great deal of the past generation's "theory" has disputed the notion that one can approach a text in an unmediated fashion. ${ }^{21}$ Therefore,

18 TFH, p. 55.

19 TFH, p. 57.

${ }^{20} T F H$, p. 58. The notion of a "You" in a text may remind American readers of Martin Buber. Yet the claim that knowledge - particularly knowledge in the humanities - required a kind of empathy that "re-constructed" the thoughts of others was well established in the German intellectual tradition. A important figure in this respect, and an author with whom Buber and Kaufmann were familiar was Wilhem Dilthey (1833-1991). His Einleitung in die Geisteswissenschaften has been translated into English as Introduction to the Human Sciences (Princeton: 1985), ed. Rudolph A. Makkrel and Frithjof Rodi. Even if one disagrees with some of Dilthey's main contentions, more familiarity with this work would enrich the debate of the humanities in the US.

${ }^{21}$ Without question, one of the abiding concerns of twentieth-century literary criticism has been the effort to demonstrate the ostensible naiveté of presuming unproblematic "given meanings in the interpretation of texts. For a now standard work in this regard see Stanley Fish's Is there a Text in this Class: The Authority of Interpretive Communities (Harvard: 1980). Kaufmann, for his part, never spoke of time- 
isn't there something naïve about Kaufmann's contention that students can access the distinctive "You" in any given text. Second, isn't what Kaufmann has to say obvious? After all, who consciously argues for parochialism in the reading and teaching of texts? Kaufmann, therefore, will never convince those he is most trying to reach.

These two objections, placed together, are somewhat contradictory. However, they add up to a consistent enough claim that what Kaufmann said is familiar, and hasn't the force to challenge current ways of doing things. In such a case, it is pointless to respond to these objections with the contradictory assertion that Kaufmann is, indeed, relevant. That will only convince those already on Kaufmann's side. Rather, the best approach is to practice a bit of what he preached and to spend a bit of time uncovering Kaufmann's own, distinctive presence. In particular, it is most helpful to bear in mind that Kaufmann had a hyphenated identity, not so much "German-American," as "refugee-American." Kaufmann grew up in Berlin, and probably never would have come to America had it not been for the Nazi persecution of the Jews. Indeed, he says as much in The Future of the Humanities. Escaping, alone, to the US in January, 1939, he enrolled for his BA at Williams College. He was seventeen at the time, and though we may consider a BA the obvious choice, Kaufmann thought in European terms, and believed that his natural path was to proceed straight on to specialized study of philosophy. "Having graduated from a German secondary school," he wrote, "I could have entered a university and obtained a doctorate in three years, had it not been for Hitler." 22 As it turned out, his education was much more American than he anticipated, and in many ways he profited from the fact that he did not become a typical product of the German system, but was, so to speak, a hybrid of Jewish Central-European and American sensibilities. ${ }^{23}$

less and pre-discursively given meanings. Rather, his concern was that, in the search for meaning, people did not abandon what Nietzsche called "the intellectual conscience" or the careful reflection on objection and alternate arguments.

22 TFH, p. 165.

${ }^{23}$ It should be mentioned that, as a teenager, he knew Martin Buber personally, and some of his ideas about a "distinctive You" were formed under Buber's influence. Also, at Williams, Kaufmann studied with James Bissett Pratt (1875-1944), a mostly forgotten scholar who was one of the founders of the comparative and psychological study of religion in America. Pratt was a clear, thoughtful and thorough 
All this is essential background for understanding Kaufmann's case, since his thoughts on education arose directly from his experience in both the old and new worlds. Like other Jewish émigré scholars-Hannah Arendt, Leo Strauss and Karl Popper come to mind-Kaufmann was preoccupied with the concern that civilization not succumb to the forces of organized irrationality. Yet, Kaufmann was younger and more "Americanized" than these writers. He very much appreciated the world of learning he was brought into. He said that "in a way a good liberal arts college is an isle of the blessed in a cruel world," going on to add:

I can think of no better way of showing this then to recall my own experience of coming to such a college in 1939. I had left Nazi Germany, crossed the Atlantic in a hurricane, and suddenly found myself in an altogether different world. In ever so many tangible ways, I encountered freedom. The students could pursue their intellectual interests and the professors could do the same. It would have been boorish to ask about the purpose of all of this; it was so beautiful. ${ }^{24}$

Nevertheless, what is beautiful may not be up to the challenges the world presents. Kaufmann noted that on the eve of America's entry into World War Two (in which a number of his fellow students were to die), Williams College, "might almost as well have been on the moon," ${ }^{25}$ so distant did it seem from the catastrophes unfolding in Europe and Asia. Exacerbating this tendency, and making it more harmful, was an ongoing spiritual insularity:

It was in those days that it was considered admirable for a teacher to be Socratic... But it was difficult to find professors who ran any risk of ever being accused of impiety, as Socrates was. One was genteel and did not think of questioning the faith and morals of one's society - at least not in one's own way, without the support of any rival creed or ideology, like Socrates. ${ }^{26}$

writer. His books can still be read with profit. See his, The Religious Consciousness: A Psychological Study (Macmillan: 1920).

${ }^{24}$ TFH, p. 165.

${ }^{25}$ TFH, p. 166.

${ }^{26}$ TFH, p. 167. 
America's victory, The Cold War, and all its attendant social transformations forever changed the American university, moving away from what Kaufmann called "the age of teacups" to the "age of specialization." ${ }^{27}$ In this era- one that is still with us - research, expansion of capacities and technique and professionalization dominate individual and collective agendas. Kaufmann was not utterly opposed to specialization (the same way he was not utterly opposed to the sheltered freedom of the old-fashioned liberal arts college). Yet, as he saw it, "some realize that specialization is an indispensable propaedeutic. Others go on to specialize more and more to become great experts on something so small and often trivial that nobody except a few other pedants in the same boat would ever like to hear about it. That is the direction in which the humanities have moved since the fifties and they did not start from scratch even then." ${ }^{28}$ Exacerbating matters was the fact that Kaufmann felt students were arriving at universities without the mastery of basic skills that would enable them to focus on their studies, making disciplined progress from there. Thus, at the worst, a small circle tends to cultivate the humanities in an overly narrow fashion, while the majority dabbles in the humanities without any though understanding of how to advance. ${ }^{29}$ For different reasons, members of each group are unlikely to be reached by the material to which they are exposed.

27 An interesting "macro" overview of the events Kaufmann describes in found in Bruce A. Kimball's A Orators and Philosophers: History of the Idea of Liberal Education (College Entrance Examination Board: 1995). Much of Kaufmann's account is commensurate with what Kimball reports, though Kimball sees the roots of specialization beginning in pre World War II days.

28 TFH, p. 175.

${ }^{29}$ Kaufmann's praise of self-discipline is best understood in light of his appropriation of Nietzsche. On p. 162 of $T F H$, he wrote that, "without self-discipline there is no mastery of any kind, nor autonomy, nor creativity that keeps on yielding satisfaction. Self-discipline is not enough, but those who lack it head for slavery or despair, or both." Despite the notion, popular in some quarters, that Nietzsche preached a wild liberation from all restrain, in his own work on Nietzsche, Kaufmann emphasized Nietzsche's arguments in favor of self-mastery, and his conviction that self-overcoming is the precondition for all educational progress. Along these lines, the one specific recommendation Kaufmann made for pre-college education is to point out that "children will soon cease to get much satisfaction from their work if they do not feel that they are making progress and can point to an occasional triumph.” (p. 162) Turning everything into progress and triumph and treating that as the only possible outcome undermines education. To see how this follows from Kaufmann's understanding of 
These conclusions leave more to discuss. However, they do provide some insight into Kaufmann's “distinctive You." What mattered to him was that the expanded, ever more market driven, pursuit of the humanities on American campuses not squander its opportunities to provoke Socratic questioning and critical self-reflection. ${ }^{30}$ After all, Kaufmann saw himself what happened when these virtues were lost.

5.

Of course, this does not directly answer the concerns raised earlier. What distinguishes Kaufmann's suggestions from other critiques (and complaints) about the state of the humanities? Here, we can turn to a specific proposal Kaufmann made for a course in comparative religion. As Kaufmann's friend, Saul Goldwasser, rightly pointed out, for Kaufmann, "religious texts provide the perfect subject matter for Socratic scrutiny, and dialectical reading." 31 Kaufmann made this point by noting that, "it is in religion that faith and morals are encountered par excellence, and in different religions, if not different sects and phases of the same ones, we find radically divergent faiths and moral views." 32 His proposed one-term course would cover parts of the Old and New Testaments, the Koran, The Dhammapada, The Bhagavad-Gita, the Confucian Analects and the Tao-Teh-Ching. ${ }^{33}$ The most important consequence of the course would be that students see that these works do not necessarily say what they think religion teaches, and that compared to each other, all outline distinctive ways of life, ones that spark an existential awareness of human choices and limitations.

Thus, Kaufmann's view should not be equated with the conservative notion that there is a set canon of unchanging classics and

Nietzsche see p. 216 of his short essay "How Nietzsche Revolutionized Ethics" reprinted in From Shakespeare to Existentialism (Princeton: 1979, first published 1959).

${ }^{30}$ Kaufmann's student, Ivan Soll, argued that though Kaufmann did not live to see the predominance of postmodernism in certain sectors of academia, what he has to say about the abandonment of meaning as an intellectual ideas remains relevant today. See Soll's introduction to Discovering the Mind, Volume Two: Nietzsche, Heidegger and Buber (Transaction: 1991, first published 1980).

31 Introduction, $T F H$, p. xxi.

32 TFH, p. 129.

${ }^{33}$ For a full outline of the course, see TFH, p. 134-36. 
enduring verities. Rather, each text has its own history, and students should grasp something of the conflict-laden manner in which it took shape and developed. By the same token, seeing texts historically does not entail reading one's own ideas into a work, or substituting more amenable texts for those that have been, historically, most challenging and influential. Kaufmann charged that, "more and more students graduate from college having read a lot of recent articles and books that are but a short while later as dated and forgotten as of most of last year's headlines. Meanwhile, even art historians rarely know the Bible." 34

What, specifically, made Kaufmann's proposed course better? Two advantages can be singled out. First, they would treat religious texts in an interdisciplinary fashion. In Kaufmann's understanding, those within a disciplinary specialty should take the trouble to explain clearly to those outside it why they thought one way, rather than another. Such efforts are central because "they force us to step back sufficiently to see the context of our specialty and become aware of our assumptions." 35 In an undergraduate class, the instructor may have to "play all the disciplines," but the students should acquire some sense of what it does and does not mean to look at a text in different ways. Second, his course encouraged students to think about translation, broadly defined. Kaufmann did not simply suggest that "The Bible" be assigned to students. He wanted those unable to read it in the original to, at least, compare various translations, and think about meanings and perspectives that might be lost. This was not a minor concern for him. He devoted a section of The Future of the Humanities to discussing translation and its problems. A comment he made on the failure to take notice of these matters reveals something of his overall pedagogical goals. The smaller issue under discussion was the fact that Freud is often read exclusively in what is called "The Standard Translation." Kaufmann used this to make a larger point:

Freud was one of the greatest writers of our century, and he is extremely difficult to translate. Anyone who tries to translate no more than the quotations he needs in a scholarly discussion

\footnotetext{
${ }^{34}$ TFH, p. 21.

35 TFH, p. 42.
} 
of Freud quickly finds how much is lost in the process. Moreover, Freud, more than anyone with the possible exception of Nietzsche, has taught us to attend to nuances, and it is odd that people writing seriously about him should feel no need whatsoever to do so.

In the classroom, the goal would be to guard against such parochialism by making the difficulties of translation an ongoing spur to candor and self-reflection. Indeed, consideration of the hazards of translation is an initial step in a path of discovery. By this method, students truly would be exposed to alternative world views. Hence, they would be forced to decide what speaks for and against them.

6.

But doesn't every teacher of the humanities try to do all this anyway? This is a difficult issue because if one speaks in generalities there is a tendency to amalgamate Kaufmann's concerns to a generalized quest for "engagement" that is very common in the literature on the humanities and its pedagogy. ${ }^{36}$ Hence, I want to conclude with a brief comparison between Kaufmann's approach and other, popular, ideas. First, it is worth noting that Kaufmann's ideas cut across ideological divides. Take, for instance, a debate on "active learning" or a "student centered classroom." By Kaufmann's standards this could cut either way. Students given informal or community building exercises may engage the spirit of a text more closely, and then again, they may not. The important issue is the discovery of a "distinctive You" in a challenging text. We should not lose sight of this goal.

This leads to a second point, one where we can introduce Gerald Graff. He has argued that have argued that humanities instructors

${ }^{36}$ One possible point of departure would be to ask students in education schools to compare the ideas on critical engagement they found in Kaufmann (and perhaps also Jacques Barzun, with whom Kaufmann shares certain similarities) with the ideas on critical engagement that they find in current pedagogical theory. The goal would not be to disparage what is recent in favor of Kaufmann, or vice versa, but to get them to reflect on their own training, and to think about which tasks in the humanities for which they are being prepared, and which they will have to make up on their own. Irresistible, incidentally, is Barzun's comment that "education in the Unites States is a passion and a paradox. Millions want it and commend it, and are busy about it, at the same time as they are willing to degrade it by trying to get it free of charge and free of work." The House of Intellect (Harper \& Brothers: 1959). 
should "teach the conflicts," which in practice means that they should be introduced to secondary, critical literature, and then clarifying to students what is at stake in this academic conversation. While I share a number of Graff's concerns, from a Kaufmann-ian standpoint, it is worth asking whether there truly is an academic conversation, or only a series of time-bound and sectarian controversies. After all, reading and discussing six scholarly articles on St. Thomas Aquinas may help students form their own ideas about him, but then again it may not. Suppose four of those articles accepted all of St. Thomas' presuppositions unquestioningly, while a fifth denounced him for being a tool of feudal landlords, and the six is not really interested in anything except the ways some ideas from the Summa Theologica can be taken from their original context and used to endorse the ideas of a much different philosopher who lived hundreds of years later. To be sure, even if Graff will not use a term like "spirit of the text," he does want the scholarly criticism that students read to direct attention to uncovering the text's possible meanings.

But what are students then to do after they use secondary sources to uncover possible meanings? In Beyond the Culture Wars, Graff approached this issue in a sidelong fashion by maintaining that since "there is, alas, no trouble free zone of reading,", we might as well avoid turning our classes into "noncommunicating monologues" and teach the intellectual controversies about what this meaning is. If students were taught these intellectual conflicts over a poem like "Dover Beach," then, according to Graff, "they might also find it easier to make out the sense of the poem, for the controversy over it might give them the sort of context for reading it that they probably lack." Yet, immediately after saying this, Graff attaches a significant condition, namely that:

The controversy would have to be presented in a way that avoids the pedantry, obscurity and technicality to which academics are notoriously prone. And even when these vices are avoided, some students will have as much trouble seeing why they should interest themselves in a critical debate over "Dover Beach" as in "Dover Beach" itself. ${ }^{38}$

37 Beyond the Culture Wars, p. 56.

38 Beyond the Culture Wars, p. 57. 
Graff goes on to attribute students' indifference or incomprehension to their "alienation from academic intellectual culture," 39 which leads him to the conclusion that this "is all the more reason for teaching the debate." ${ }^{40}$ But putting it this way simply leads us back to the place that Kaufmann began, i.e., the task of letting the text somehow challenge our ideas and beliefs. ${ }^{41}$ If humanities instructors have no clear idea of this, how will they ever know whether they are indeed overcoming student alienation and teaching conflicts? As Kaufmann

39 Beyond the Culture Wars, p. 57.

40 Beyond the Culture Wars, p. 57.

${ }^{41}$ It is unfair to Graff to sum up the contents of two books without providing at least one extended illustration of the problem I am criticizing. For this reason, I want to give one example, if not to settle the matter, then at least to clarify why I've reached my conclusion. As part of his argument in the "Clueless" book that student writing can be improved if they enter into conversation with ongoing scholarly debates, Graff introduces the case of "Ellen," a student writing on the novel Things Fall Apart. Ellen has said that the protagonist, Okwonko is a "tragic hero," and Graff thinks her flat writing can be improved if she adds a "so what" question. To illustrate what he meant, Graff gave his own re-working of Ellen's thesis, should she try to write it at a higher level like "trying to get it published or submitting it as a Master's thesis." His version reads:

"Though in obvious ways an evil man, Okonkwo nevertheless achieves a kind of tragic stature in the colonialist setting of the novel. As a residual African tribesman whose culture is being destroyed by the forces of colonialism and modernization that arrive in the novel's final chapters, Okonkwo is as much the tragic victim as the victimizer of others. On the other hand, though Okonkwo might be a victim to most postcolonial readers, he would certainly be a victimizer to feminists." (all quotes, p. 162)

This introduction of a "naysayer" into the text shows that it is possible to do so without ever grappling with the problems of the text. Just as the high-school student, Ellen, could have uncomprehendingly repeated platitudes about Okonkwo being a "tragic hero," so too the master's student, Ellen, could have safely repeated the scholarly commonplaces of various academic groupings without ever challenging herself to think about what it means to use the term "evil" in reference to Okwonko, or to ask what his "tragedy" does to her understanding of the world. In the worst case, it is easy to imagine someone writing fifty pages of the most learned, reference-laden prose without ever going beyond a timorous deference to established writers who are treated as moral and intellectual authorities. Graff does not desire such blandness, but, without Kaufmann's approach, it is an open question as to whether he can guard against it. In this respect, see writing manual he recently co-wrote with Cathy Birkenstein, "They Say/I Say" The Moves that Matter in Academic Writing (Norton:2006). This book has a number of excellent suggestions for pushing writers (not just students) to think more carefully about their arguments and ask themselves "who cares." Yet if the way they answer that question is to look to outside authorities, they may never discover the "intellectualism" that Graff and Birkenstock seek. 
put it, "every reader tends to see what he likes and not see what makes him uncomfortable. Least of all does one think of the author as a human being like oneself." 42 Humanistic education will only be effective if it strives to overcome this partial vision. Pedagogy aiming to "teach the conflicts" should be informed by the Socratic ethos that Kaufmann evokes. Indeed, for college students to profit from teaching the conflicts at all their earlier education must prepare to have high standards of responsibility in making intellectual judgments. Graff seems to want these standards, but does not talk about what they are or how students are to obtain them. This point was brought out well in a perceptive and critical review of Clueless in Academe by Sandra Stotsky. She made the point that college English students are unlikely to use Graff's guidelines to integrate themselves into intellectual culture if, earlier, "they have not learned that they must first read and try to understand what the author wrote." ${ }^{, 43}$ From this perspective, Kaufmann's work is not only relevant for debates in higher education, but for discussions of education as a whole.

\section{7.}

In the end, Kaufmann re-directs attention from questions about technique and sectarian academic schools to focus it on purposes and goals. One of the nastiest - but I think one of the most helpful - comments he made in his book concerns the doleful consequences of an academic system that discouraged reflection on these themes:

For roughly twenty years, from about 1950 until 1970, large numbers of students entered graduate schools and then went on to teach philosophy, or history, or religion, literature, or art, without ever having seriously reflected on their goals.

${ }^{42}$ TFH, 188.

${ }^{43}$ Review of Graff's Clueless in Academe, Sandra Stotsky (American Journal of Education, volume 112 (2005), p. 149-152. It can also be noted that the example Graff provided of Ellen writing about Okwonko's "tragic flaw" testifies to a student who, apparently, was not pressed to clarify to herself the meaning of what she read. After all, the meaning of tragic flaw or harmartia derives primarily from Aristotle's Poetics. Like everything else treated in that slim work, its meaning is outlined only briefly there, and has subsequently received centuries of the most conflicting exposition. Whether it is useful to apply the concept to Achebe's 20th-century novel all depends on what Ellen understands the book to mean. This was Stotsky's point in the first place. 
Going into graduate work was rarely experienced as a fateful plunge; on the contrary, it meant staying in school for a few more years, a prolongation of the status quo. ${ }^{44}$

Kaufmann concluded:

Obviously, something had gone wrong in education some time before this. When so many people trained in the humanities, and quite especially in philosophy had examined their own lives and goals so little, their own training must have been a far cry from the heritage of Socrates. ${ }^{45}$

As I see it, this is not a personal swipe (or, not only one). Instructors willing to reflect on their own goals probably (perhaps not invariably) will be willing to reflect on and confront the intertwined goals of a text. ${ }^{46}$ This starts the "culture shock."

8.

Practical suggestions (or an elaboration on what Graff called the "so what" question). Both those sympathetic and unsympathetic with everything said so far will want to know whether The Future of the Humanities has indeed actually shaped anyone's teaching. Here are two ways it influenced mine:

- Kaufmann's book strengthened an already held opinion that what is really at stake in the humanities is honesty. In particular, Kaufmann's book makes a good case that humanities classes should be "Socratic" in the sense that they enable us to identify unexamined assumptions in past and present civilizations, and then consider their viability. In practice, this means that the texts I assign (my canon) are

44 TFH, p. 176.

45 TFH, p. 177.

46 The philosopher, Martha Nussbaum has gone on record saying that "one thing that my work in development has shown me very clearly is that a public policy made without the influence of the humanities is likely to be a cramped and crude policy." Nussbaum, I believe, is not alone in this sentiment, and it is easy to think of cases where public policy could have been more effective and humane if policy makers only had a wider and deeper imagination. Still, even if this is true, it does not follow that everyone educated in the humanities has something insightful and humane to say about public policy. Only when humanistic intellectuals are truly self-critical and rigorous with themselves does this argument about public policy begin to acquire plausibility. See Nussbaum's comments in Liberal Education, Summer 2001, Vol. 87 Issue 3, p. 38. 
texts I think lead us to confront reigning values, either reaffirming or critiquing them (or both). Following this, I ask students to read and discuss the works where they must keep asking themselves whether they are truthfully identifying the texts main challenges, and whether they are grappling with these challenges with genuine candor. My writing assignments are more systematized versions of these two questions. Though my classes are for undergraduates, I see no reason why teachers of younger students could not adapt Kaufmann's ideas for their own ends.

- Kaufmann's book helps one cope with the inevitable mortality of the humanities, and its possible replacement by new branches of the natural sciences. Just as the votive statues and oracle bones of past ages testify to the very large number of human values systems that have been forgotten, ignored or abandoned, so too, future generations (should there be any) could easily relegate all our current efforts to a small, esoteric, and perhaps not entirely edifying, nook in the history of the human knowledge. Nevertheless, what future generations might or might not think should not influence us. Someday people may eliminate the need for rational discussion, the encounter with distinctive points of view, and the honest consideration of alternatives. Until now, the natural sciences have not been able to come up with viable replacements for these practices. Perhaps they never will, though it seems probable that they will make some very good efforts in trying. Until then, I think the best way to think about the future of the humanities is to take Kaufmann's warnings about "blindness" to heart, and never stop reflecting on aims and goals. 


\title{
Dejvid Pikus
}

\section{VOLTER KAUFMAN I BUDUĆNOST HUMANISTIČKIH DISCIPLINA}

\author{
Rezime
}

Volter Kaufman (1921-1980) je ostao upamćen po svom delu o Ničeu. Međutim, od 1950. do kraja života, on je stvorio široki i provokativni opus filozofske kritike. U jezgru Kaufmanovih napora bila je zabrinutost za humanističke discipline i njihovu ulogu u modernom intelektualnom životu. Kaufmanovo glavno promišljanje te teme, delo The Future of the Humanities (1970) zaslužuje više pažnje nego što mu je do sada bilo poklanjano. Ono pronalazi način da sjedini dva temeljna cilja savremene teorije, potragu za autentičnošću i želju za promovisanjem kritičkog duha. Tema ovog članka jeste način na koji je Kaufman postigao te ciljeve, a što svedoči o njegovoj trajnoj relevantnosti za one kojima je stalo do humanističkih disciplina.

Ključne reči: humanističke discipline, autentičnost, kritički duh. 